\title{
Case study of the winter $2013 / 2014$ extreme wave events off the west coast of Ireland
}

\author{
Jelena Janjić ${ }^{1}$, Sarah Gallagher ${ }^{2}$, and Frédéric Dias ${ }^{1}$ \\ ${ }^{1}$ School of Mathematics and Statistics, University College Dublin, MaREI Centre, Dublin, Ireland \\ ${ }^{2}$ Research, Environment and Applications, Met Éireann, Dublin, Ireland \\ Correspondence: Jelena Janjić (jelena.janjic@ucdconnect.ie)
}

Received: 28 November 2017 - Revised: 21 May 2018 - Accepted: 6 June 2018 - Published: 26 July 2018

\begin{abstract}
Using the third generation WAVEWATCH III wave model in an unstructured formulation, and driven by HARMONIE-AROME mesoscale model hourly winds with a $2.5 \mathrm{~km}$ horizontal resolution, we reproduce the winter storms of 2013/2014 and analyse their effect on the western coastline of Ireland. WAVEWATCH III was forced at its ocean boundaries by directional wave spectra obtained from the ECMWF ERA-Interim re-analysis dataset. The wave model has a high resolution grid (up to $225 \mathrm{~m}$ resolution in the nearshore) with around 20000 nodes, producing an abundance of important wave parameters outputted hourly, enabling a high quality, high-resolution analysis of the winter storms of 2013/2014.
\end{abstract}

\section{Introduction}

A significant portion of the electrical energy required globally could potentially be supplied by harnessing wave energy and waters of the northeast Atlantic are ideal for ocean energy extraction. Wave Energy Converters (WECs) transform wave energy to mechanical energy and finally to electricity. Wave energy conversion depends highly on average energy available for extraction, direction of incoming waves (for unidirectional WECs) and wave frequency/period because WECs extract the maximum energy if they are tuned to match this frequency. These wave characteristics can be described by wave parameters like wave energy flux, mean or peak direction, and various types of wave periods. In extremely energetic sea states we have a large energy resource but there is also a risk of WEC damage and Ireland has a long history of storm waves reaching its shores. Due to its position in the Northeast Atlantic, Ireland is regularly on the path of very energetic extratropical weather systems, which can bring with them phenomenal sea-states and extreme wave conditions. For this reason, developers of ocean energy devices need to take into account that although there is a huge ocean energy resource available off the west coast of Ireland, there is a percentage of extreme events like the ones during winter 2013/2014 which may cause damage to the devices. Since the buoy data in Irish waters are sparse, both in space and in time, a hindcast properly validated against available measurements will allow developers to improve WEC design and choose adequate locations for device deployment, ensuring that device operation encounters as little down-time as possible.

The storms of winter 2013/2014 had various effects on the Atlantic coast of Europe. This winter experienced beach changes (Masselink et al., 2016), severe gale strength winds, above average rainfall amounts and notable storm surges (Met Office: Winter storms: December, n.d.; Met Office: Winter storms: January, n.d.; Met Office: Winter 2013/14, n.d.; Met Éireann: December, n.d.; Met Éireann: January, n.d; Met Éireann: Winter, n.d.) causing a lot of coastal damage and inland flooding across the Atlantic coast of Europe. More than USD 1.8 billion worth of damage in the UK was estimated (RMS, 2014). A study by Matthews et al. (2014) showed that the winter 2013/2014 was the stormiest (they characterised storminess by taking into account the frequency and intensity of cyclones) in the last 143 years, again confirming that this winter was indeed exceptional.

For this reason, several studies have begun to examine if these extreme events are linked to anthropologically caused climate change (Masselink et al., 2016; Matthews et al., 2014; Wild et al., 2016). Masselink et al. (2016) proposed that it is tempting to assign these extreme events to climate 


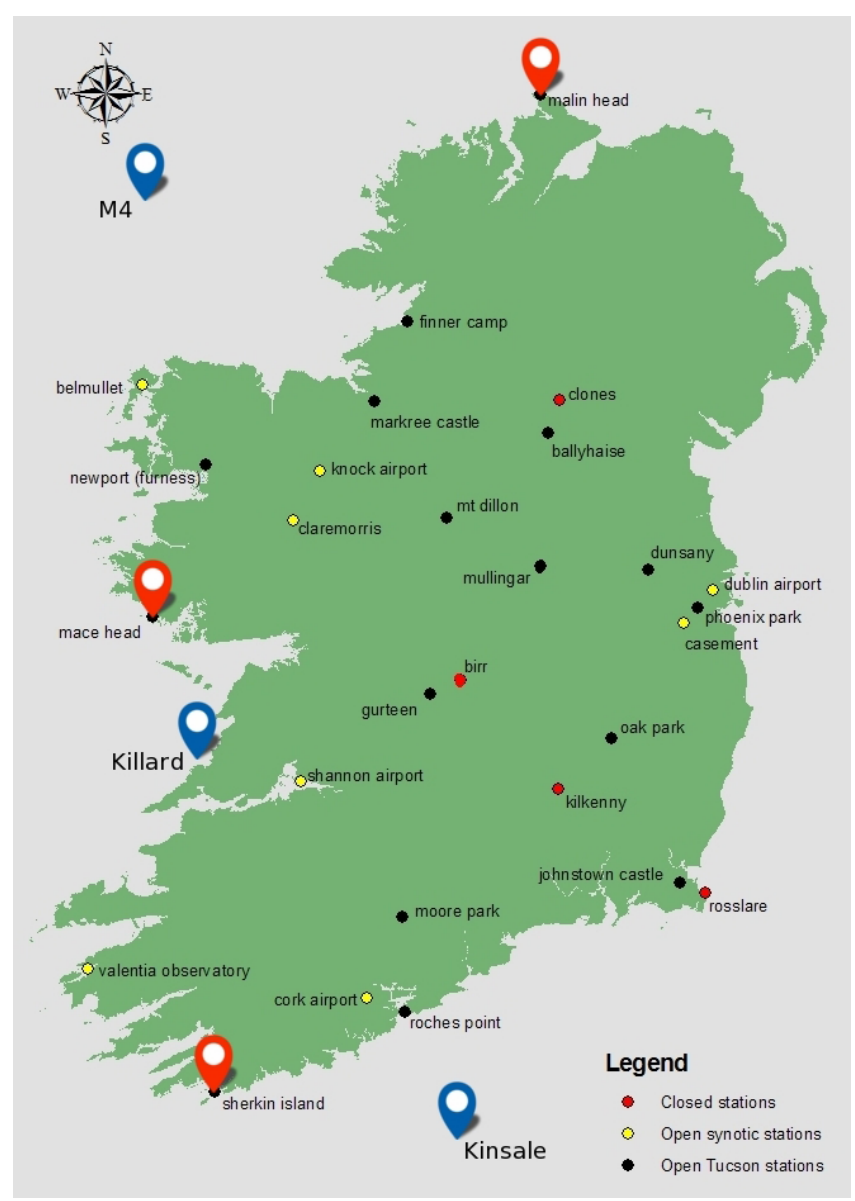

Figure 1. Map of Met Éireann stations and the location of the observations of wave and wind parameters used in this study. The location of the wave buoys used for model validation, Kinsale Gas Platform, Killard and the M4 buoy, are marked with blue pins. The location of the three TUCSON coastal stations, Sherkin Island, Mace Head and Malin Head, are marked with red pins.

change due to the predictions of increased storminess by climate models. A study by Wolf and Wolf (2013) concluded that the influence and impact of climate change on the northeast Atlantic waves and storms was still uncertain, while Wild et al. (2016) inferred that the large number of storms of the winter 2013/2014 could not be directly related to anthropogenic factors.

Looking into the future wave climate, a recent study using one CMIP5 climate model ensemble found that the number of low pressure systems and windstorms crossing Ireland by the end of the 21 st century is projected to decrease, although not significantly, with typically 10 depressions with Mean Sea Level Pressure - MSLP $<970$ hPa crossing Irish waters annually (Gallagher et al., 2016b). In an additional study, focusing on extreme wave events off Ireland, Gleeson et al. (2017) found evidence of some extreme wave enhancement under the influence of a strongly positive North Atlantic Oscillation, off the west coast of Ireland. Further studies are required to try to address the current uncertainties in North Atlantic wave and storm projections and their affect on Ireland. However, it is clear that extreme wave events are likely to continue into the future and should be planned and prepared for.

\section{Model details}

This hindcast was performed with the third generation WAVEWATCH III (WW3) wave model (Tolman, 2014) version 4.18 with an unstructured grid (Roland, 2008). The parametrization for source terms and dissipation (Test 451) formulated in Ardhuin et al. (2010) was implemented. The bathymetry used was generated using a Digital Elevation Model (DEM) for Ireland (Gallagher et al., 2014). The DEM combined three bathymetric sources: Vector data obtained from OceanWise Ltd., the European Marine Observation and Data Network bathymetric set (EMODnet, 2013) and MultiBeam EchoSounders (MBES) and LIDAR INFORMAR data from the Geological Survey of Ireland (GSI) and Marine Institute (MI). EMODnet data has a resolution of approximately $500 \mathrm{~m}$ while MBES and LIDAR INFORMAR data has a resolution from 2 to $80 \mathrm{~m}$. The unstructured triangular grid has 20235 nodes and a varying resolution of $10 \mathrm{~km}$ offshore to $225 \mathrm{~m}$ nearshore (Gallagher et al., 2016a). The limiting bottom depth for the wave model was set at $5 \mathrm{~m}$.

WAVEWATCH III is driven with HARMONIE-AROME $10 \mathrm{~m}$ wind forcing fields and ERA-Interim (Dee et al., 2011) wave spectra with a temporal resolution of $6 \mathrm{~h}$ (standard synoptic times - 00:00, 06:00, 12:00, and 18:00 UTC). The boundary feeding was set at grid nodes on segments of the open boundary (at the ERA-Interim grid points and between them) where the depth is larger than $90 \mathrm{~m}$. Spectral domain is discretized in 24 directions and 30 frequencies logarithmically spaced with an increment of 1.1 from $0.0345 \mathrm{~Hz}$. This coincides with the ERA-Interim wave spectra resolution. HARMONIE-AROME $10 \mathrm{~m}$ winds used to drive the wave model were derived from the downscaled ERA-Interim atmospheric model (Gallagher et al., 2016a). The temporal resolution of the HARMONIE-AROME $10 \mathrm{~m}$ winds is $1 \mathrm{~h}$ and a horizontal grid spacing of $2.5 \mathrm{~km}$.

\section{Overview of winter $2013 / 2014$}

The Polar jet stream marked the tracks for 12 major consecutive storms in winter 2013/2014: 5/14/18/24/26/27 December 2013, 3/25/26 January 2014, and 1/8/12 February 2014, according to Met Éireann (Met Éireann, 2017a). Inland and coastal flooding in Ireland and UK was a result of the combination of strong winds, tidal surges, low pressure and heavy outbreaks of rain (Met Office, 2014, 2015; Met Éireann, 2013, 2014). UK suffered land and air transport disruption, loss of power and even fatalities (Met Office, 2014, 2015). The majority of December monthly rainfall totals in Ireland 


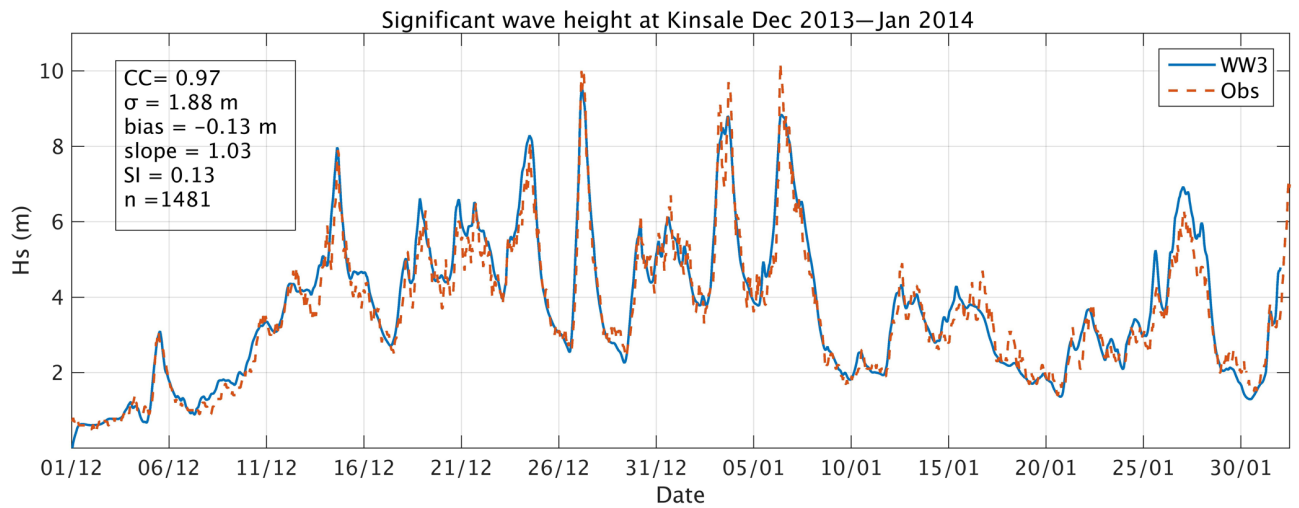

Figure 2. Timeseries of significant wave height for December 2013 comparing observations from the Kinsale Energy Gas Platform (51.37, -7.945) radar and modelled values. In the upper left corner we provided the following statistical parameters: Correlation coefficient (CC), standard deviation $(\sigma)$, bias, slope, scatter index (SI), and the number of records $(n)$.

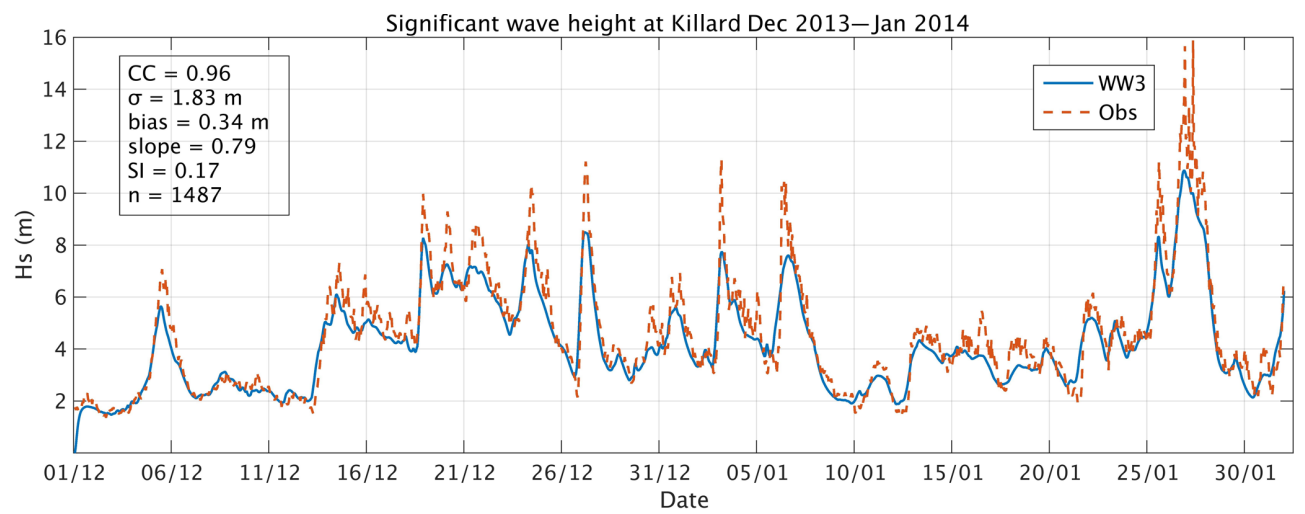

Figure 3. Timeseries of significant wave height for December 2013 and January 2014 comparing observations from the Killard (52.774, -9.587) buoy and modelled values. In the upper left corner we provided the following statistical parameters: Correlation coefficient (CC), standard deviation $(\sigma)$, bias, slope, scatter index (SI), and the number of records $(n)$.

were well above average except at a few stations in the West, East and North. Co. Kerry reported its wettest December on record since records began in 1949 (69 years) (Met Éireann, 2017c). Valentia Observatory recorded the lowest minimum monthly pressure values of $947.1 \mathrm{hPa}$ on 27 December due to a depression of $944 \mathrm{hPa}$ that was passing over the north and northwest coast. Britain, Ireland and France were under long-lasting and heavy rainfall with strong winds in the early 2014 (Met Éireann, 2017b). All the rainfall totals in Ireland for January were above their long term average rainfall. In January 2014 river and coastal flooding occurred with strong winds reaching up to $150 \mathrm{~km} \mathrm{~h}^{-1}$. Windstorm Christina (3rd to the 10th) with a low pressure centre of $940 \mathrm{hPa}$ caused substantial damage to infrastructure and coastal homes in Ireland.

\section{Methodology}

For brevity, we have chosen four of the storms that affected Ireland during the winter of 2013/2014: (i) "Xaver" on 5 De- cember 2013; (ii) "Christina" on the 3rd; (iii) "Hercules" on the 5-6th; and finally (iv) a record breaking storm on 26-27 January 2014. Each of these storms is described and discussed in detail in separate sections below. We give an overview of the storms importance and weather and wave conditions on the day of the storm. We analysed time series in three locations (M4 off the northwest coast, Killard off Co. Clare, and Kinsale Energy Gas Platform off the south coast - See Fig. 1) with maps of the significant wave height $\left(H_{\mathrm{s}}\right)$, peak wave period $\left(T_{\mathrm{p}}\right)$, and peak wave direction $\left(D_{\mathrm{p}}\right)$. We examined wind speeds and directions in three locations taken from The Unified Climate and Synoptic Observation Network (TUCSON): Malin Head, Mace Head, and Sherkin Island. These are Automatic Weather Stations (AWS) which are part of Met Éireann's synoptic weather observation network. These stations were chosen because they are both close to the coastline and the wave measurement locations. 


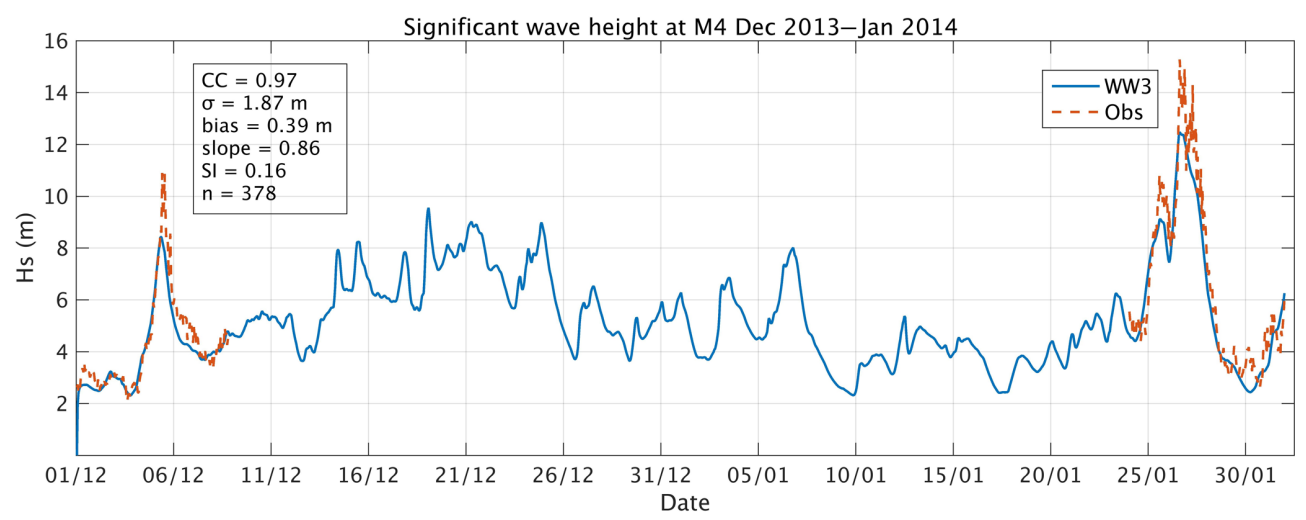

Figure 4. Timeseries of significant wave height for December 2013 and January 2014 comparing observations from the the Irish Weather Buoy Network M4 buoy $(55,-9.99)$ and modelled values. Note that the M4 buoy was non-operational for most of the period under evaluation. In the upper left corner we provided the following statistical parameters: Correlation coefficient $(\mathrm{CC})$, standard deviation $(\sigma)$, bias, slope, scatter index (SI), and the number of records $(n)$.

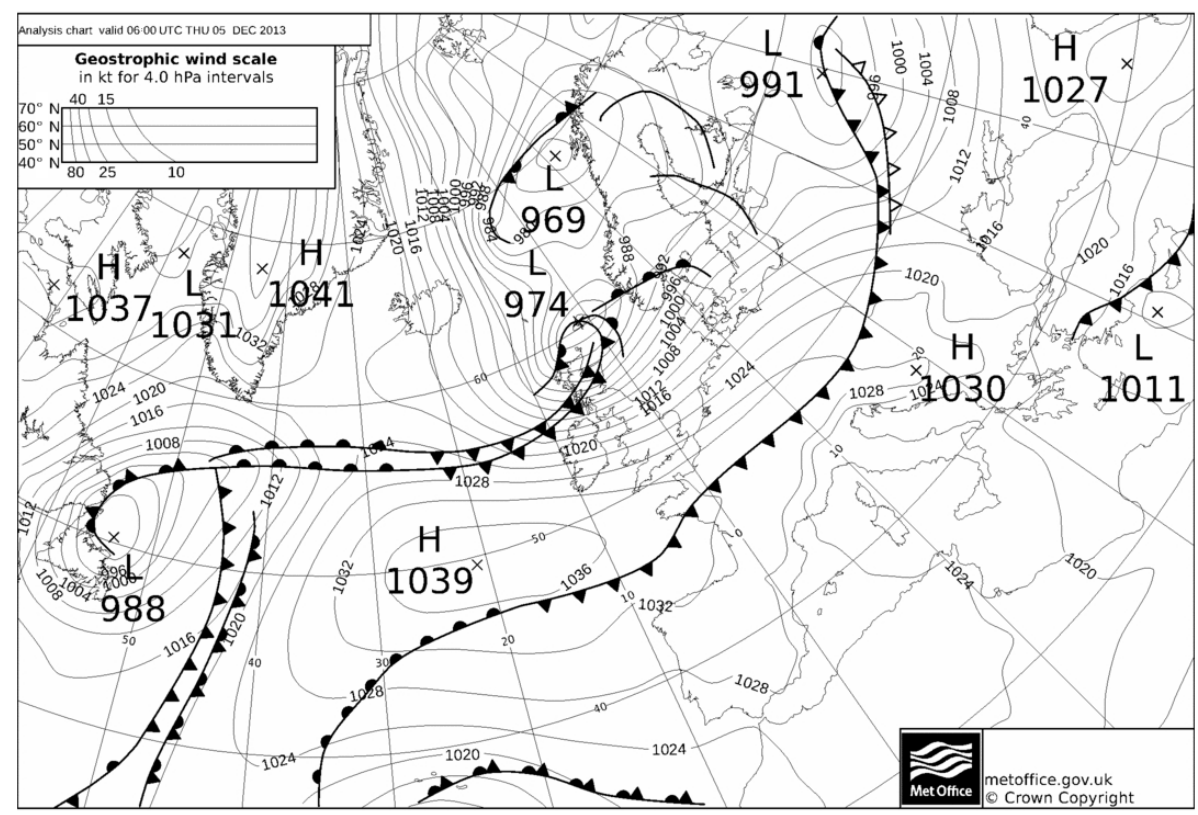

Figure 5. Synoptic chart of storm "Xaver” on 5 December 2013 at 06:00 UTC. (C Crown Copyright (Met Office, UK).

\section{Validation}

We validated the model by comparing it to the buoy data available. In Figs. 2, 3, and 4 we show the timeseries comparison at Killard, Co. Clare, the Kinsale Energy Gas Platform, and at the location of the the Irish Weather Buoy Network M4 buoy. The values of the statistical parameters for $H_{\mathrm{s}}$ at different locations are summarised in Table 1. These parameters are defined as following:

1. Pearson correlation coefficient (CC):

$$
\rho(A, B)=\frac{1}{n-1} \sum_{i=1}^{n}\left(\frac{A_{i}-\mu_{A}}{\sigma_{A}}\right)\left(\frac{B_{i}-\mu_{B}}{\sigma_{B}}\right)
$$

where $\mu_{A}, \sigma_{A}, \mu_{B}$, and $\sigma_{B}$ are the mean and standard deviation of $A$ (model values) and $B$ (measured values) respectively and $n$ is the number of records.

2. Standard deviation $(\sigma)$ :

$$
\sigma_{A}=\sqrt{\frac{1}{n-1} \sum_{i=1}^{n}\left|A_{i}-\mu_{A}\right|^{2}}
$$

where $\mu_{A}$ is mean of $A$ :

$$
\mu_{A}=\frac{1}{n} \sum_{i=1}^{n} A_{i}
$$


3. Bias:

$$
\text { Bias }=\frac{1}{n} \sum_{i=1}^{n}\left(B_{i}-A_{i}\right)
$$

4. Slope is calculated with the polyfit (degree of fit is 1 i.e. linear fit) command (MATLAB , R2015b), which solves a linear system:

$p=\frac{\mathrm{V}}{\boldsymbol{A}}$

where $\mathbf{V}$ is a Vandermonde matrix of $B$.

5. Scatter Index (SI):

$$
\mathrm{SI}=\frac{\mathrm{RMSE}}{\mu_{B}}
$$

where RMSE (Root Mean Square Error) is defined as:

$$
\operatorname{RMSE}=\sqrt{\frac{1}{n} \sum_{i=1}^{n}\left(B_{i}-A_{i}\right)^{2} .}
$$

It can be seen that the model mostly underestimates the values of $H_{\mathrm{s}}$ at the Killard wave buoy (bias $=0.34 \mathrm{~m}$ ) and M4 (bias $=0.39 \mathrm{~m}$ ) while slightly overestimating at Kinsale (bias $=-0.13 \mathrm{~m}$ ), indicating that the model settings could be improved to try to reduce the bias. As seen in Fig. 4 only $25 \%$ of hourly records have been available for the observed period. Using the values of the Pearson correlation coefficient, we can see that we have a strong relationship between the measured and modelled $H_{\mathrm{S}}$ with a slightly more pronounced correlation at Kinsale and M4 (0.97) than at Killard (0.96). For Killard, Kinsale, and M4 we have a positive relationship with Kinsale and M4 having a higher slope closer to 1 . The agreement could be improved by feeding the model with 2-D spectra from the ECMWF operation archive, and by refining the wind input and dissipation scheme used in the model. The HARMONIE-AROME $10 \mathrm{~m}$ wind input used to force the wave model for this study was previously validated thoroughly by comparison to over 120 land and buoy stations and altimeter data in Gallagher et al. (2016a).

\section{Results}

\subsection{Storm "Xaver" on 5 December 2013}

The storm on 5 December was the first storm of the winter of 2013/2014. This storm, named Xaver, formed off the coast of Greenland on 4 December, moved over Northern Europe up until 7 December. The low pressure system passed northwest of Ireland with values from $987 \mathrm{hPa}$ at 00:00 UTC to $967 \mathrm{hPa}$ at 12:00 UTC on the same day (Fig. 5) causing a notable storm surge and coastal flooding across Northern Europe. According to the Met Éireann Monthly Weather Bulletin for December 2013, there were some heavy outbreaks
Table 1. Statistical parameters.

\begin{tabular}{lcrrrrrr}
\hline $\begin{array}{l}\text { Location } \\
\text { name }\end{array}$ & $\mathrm{CC}$ & $\begin{array}{r}\sigma_{A} \\
(\mathrm{~m})\end{array}$ & $\begin{array}{r}\sigma_{B} \\
(\mathrm{~m})\end{array}$ & $\begin{array}{r}\text { Bias } \\
(\mathrm{m})\end{array}$ & Slope & SI & $n$ \\
\hline Kinsale & 0.97 & 1.88 & 1.79 & -0.13 & 1.03 & 0.13 & 1481 \\
Killard & 0.96 & 1.83 & 2.21 & 0.34 & 0.79 & 0.17 & 1487 \\
M4 & 0.97 & 1.87 & 2.93 & 0.39 & 0.86 & 0.16 & 377 \\
\hline
\end{tabular}

of rain on the 5th and 6th with gusty conditions (Met Éireann, 2017c). Although not a substantial storm over Ireland, it wreaked havoc along its trajectory over parts of northern Europe and Scandinavia.

After moving away from Ireland, the storm continued to track over the UK, northern Europe and Scandinavia, causing record breaking water levels along the German North Sea coastline (Dagendorf et al., 2016) and high seas and storm surges in UK coastal waters (Wadley et al., 2014), resulting in thousands of flooded homes. It caused the rail network in Scotland to shut down, with power losses, flight cancellations, fallen trees, traffic accidents, storm surges, and fatalities in the UK (Met Office, 2017c).

In Fig. 6 we show the wind speeds, gusts and direction on 5 December for Malin Head and Mace Head which were affected by gale and storm force mean wind speeds as the low pressure system tracked to the north-west of Ireland, with winds gusting as high as $65-70 \mathrm{kt}$ at Malin Head in the north of the country for a time. A substantial drop in the wind speeds and a change in the direction from westerly to north westerly can be seen between 10:00 and 11:00 UTC, as a cold front from the system passes over the stations.

The wave model simulation produced maximum $H_{\mathrm{s}}$ values of $9.25 \mathrm{~m}$ at 08:00 UTC on 5 December in the North Atlantic ocean $27 \mathrm{~km}$ north from Tory Island, Co Donegal. The peak wave direction ranged from 270 to $300^{\circ}$ and the peak wave period was between 12 and $14 \mathrm{~s}$ during the day (Fig. 7).

\subsection{Storm "Christina" on 3 January 2014}

Overnight rainfall continued throughout the day on 3 January 2014 and into the evening hours across most of Ireland. Winds ranged from strong to strong gale and were south to southwest direction according to the Met Éireann Monthly Bulletin for January 2014 (Met Éireann, 2017b). Valentia Observatory recorded the months lowest pressure value of $956 \mathrm{hPa}$ in the early hours of 3 January 2014 as this Atlantic depression passed close to the western coast, which can be seen in Fig. 8. Flooding occurred in Dublin, Cork, Galway, Salthill, Waterford, Tralee, Clare and Mayo, with the rivers Shannon and Liffey bursting their banks. The Limerick flooding was a consequence of a combination of high tides, strong winds and heavy rainfall (Irish Times, 2014). Approximately 2800 customers in counties Donegal, Mayo and Clare were reported by ESB Networks to be without power after strong winds and heavy rain overnight. Wales, 
(a)
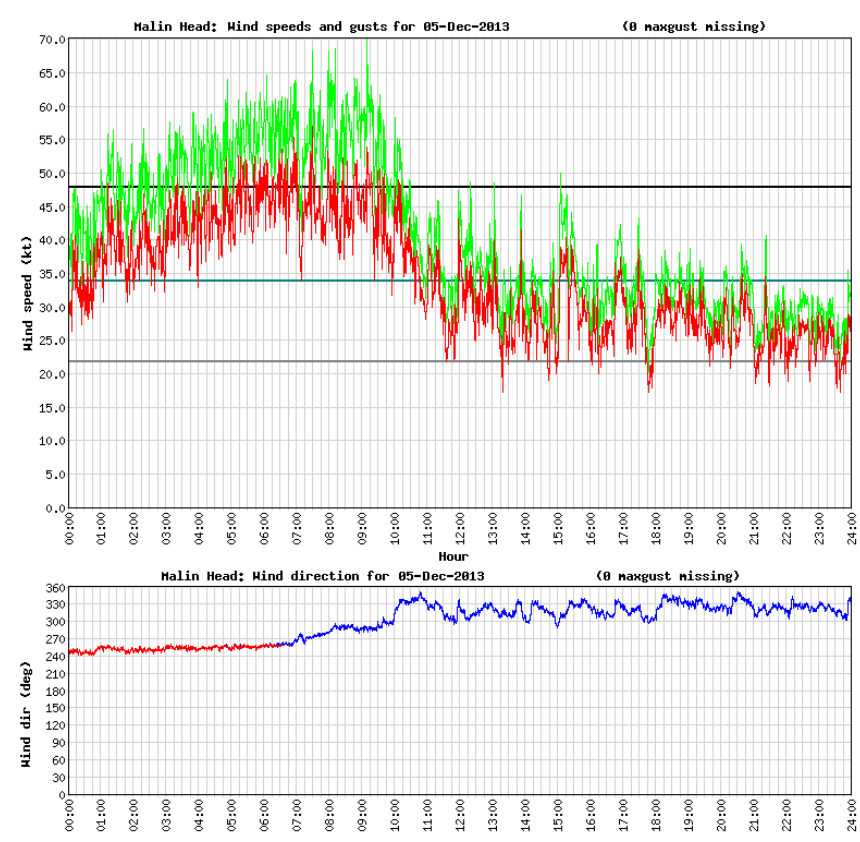

(b)

\section{Mace Head}
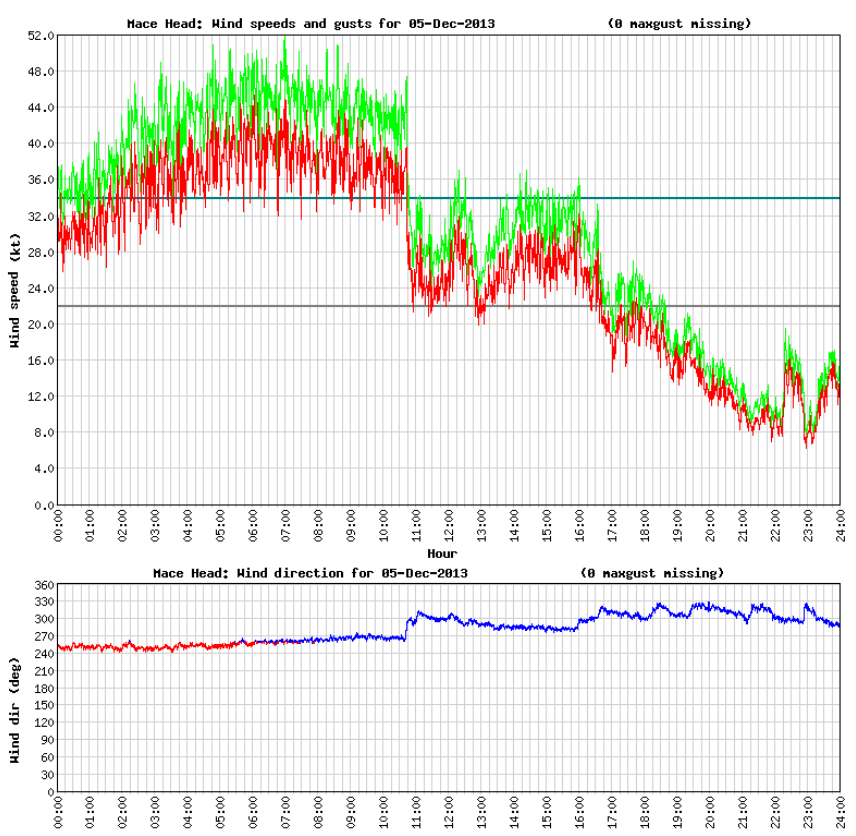

Figure 6. Observations from Met Éireann Synoptic (TUCSON) stations at (a) Malin Head and (b) Mace Head for wind speeds and gusts (top panels) and direction (bottom panels) on 5 December 2013. Top panels: Red = wind speed (kt); Green = wind gust (kt). For context, horizontal lines show mean speed boundaries on the Beaufort scale. Grey = Force 6 "Strong breeze" (22 kt); Turquoise = Force 8 "Gale" $(34 \mathrm{kt})$; and Black = Force 10 "Storm" (48 kt). Note the different scales for wind speed. Bottom panels: Direction of wind speeds and gusts $\left({ }^{\circ}\right)$.
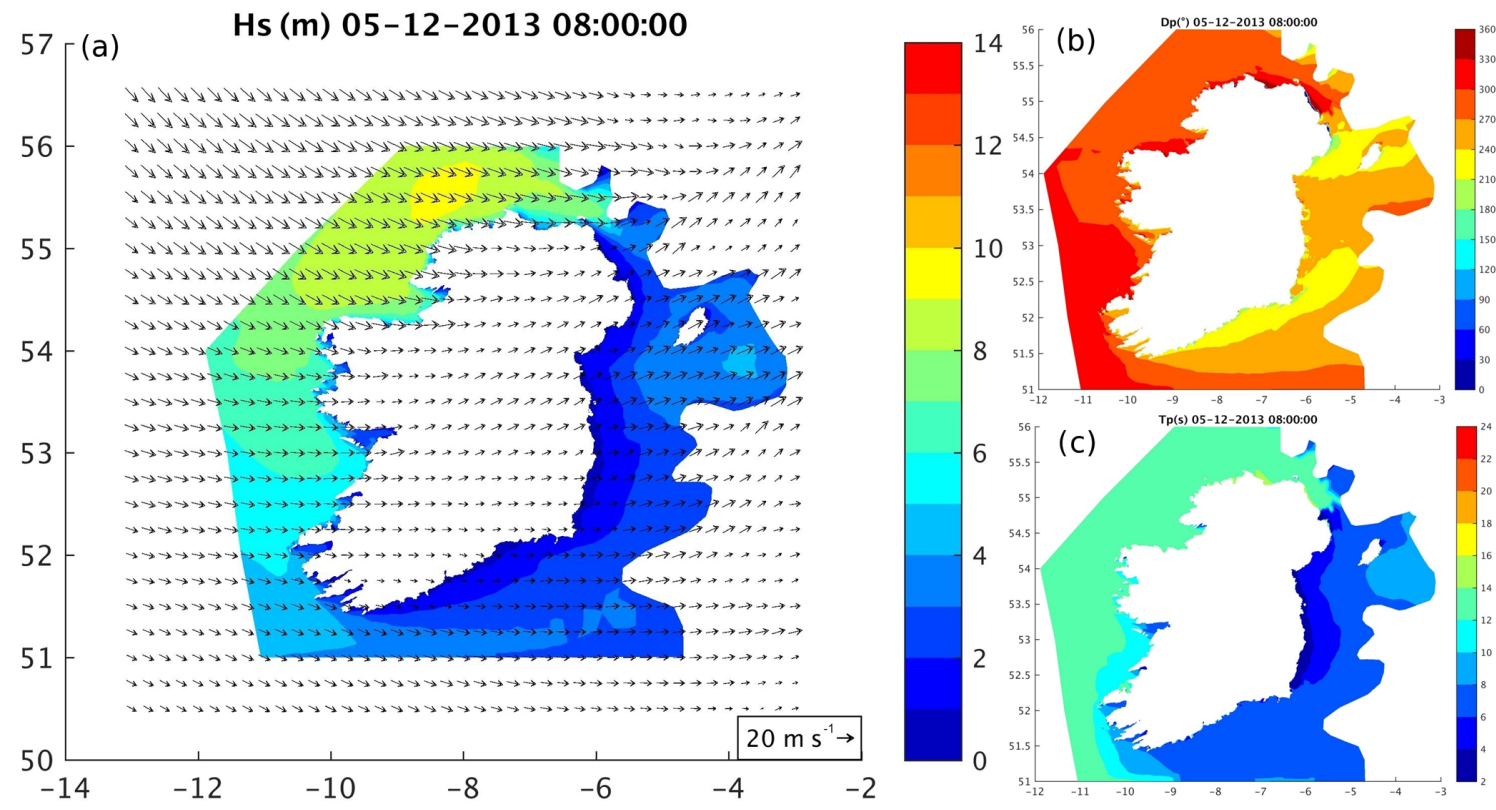

Figure 7. Maps of (a) significant wave height $(\mathrm{m})$ with vectors representing wind speed $\left(\mathrm{m} \mathrm{s}^{-1}\right)$ and direction $\left(^{\circ}\right)$, (b) peak wave direction $\left({ }^{\circ}\right)$, and (c) peak wave period (s) at 08:00 UTC on 5 December 2013. 


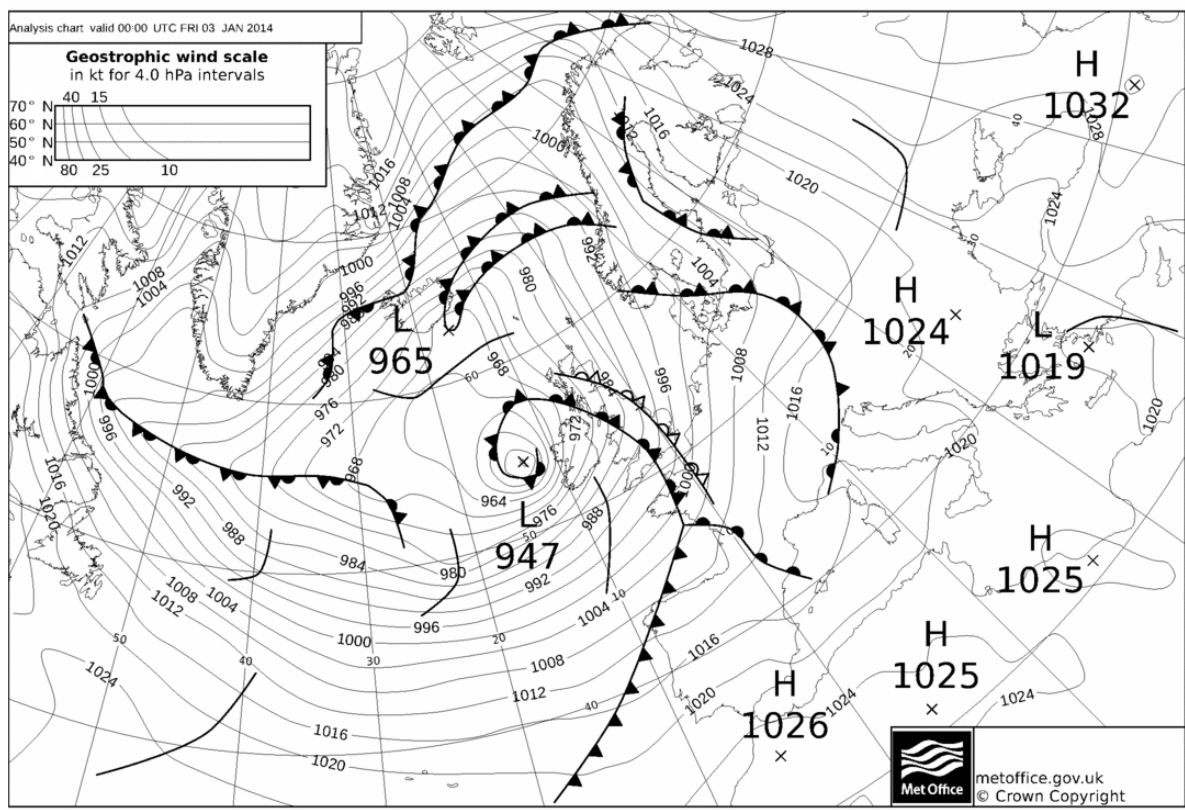

Figure 8. Synoptic chart of storm "Christina” on 3 January 2014 at 00:00 UTC. @ Crown Copyright (Met Office, UK).

(a)
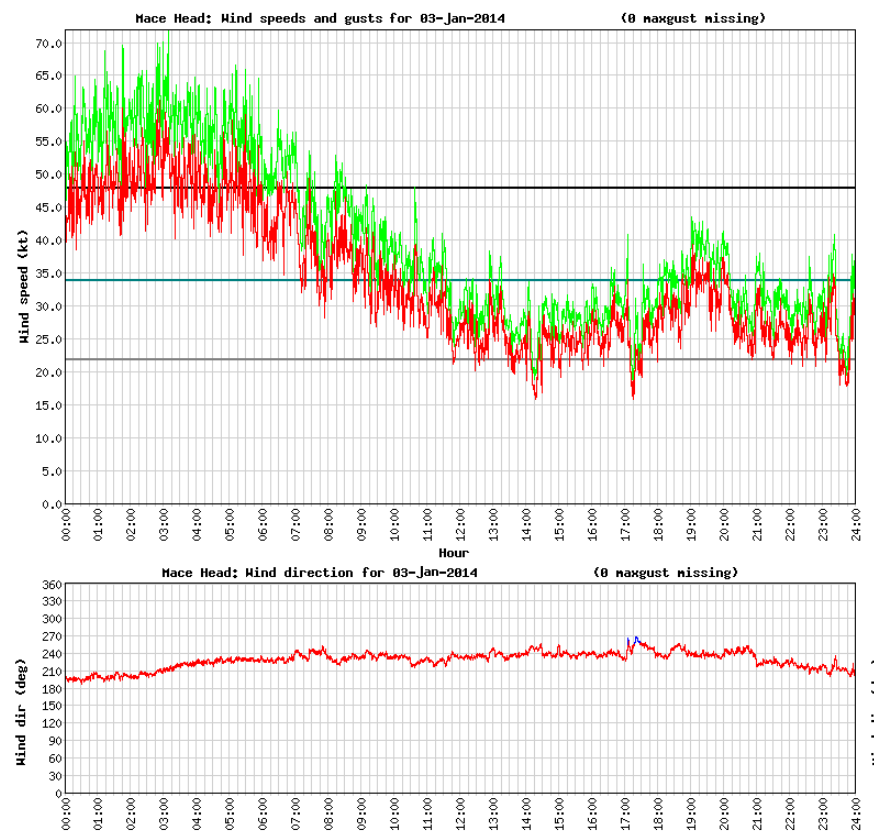

(b)
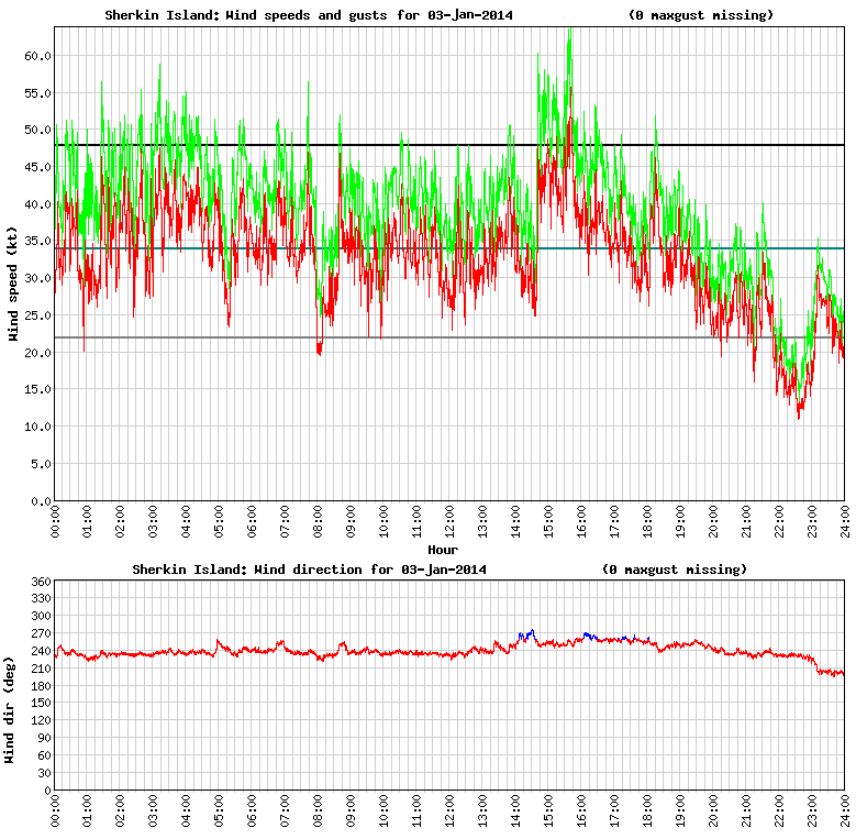

Figure 9. Observations from Met Éireann Synoptic (TUCSON) stations at (a) Mace Head and (b) Sherkin Island for wind speeds and gusts (top panels) and direction (bottom panels) on 3 January 2014. Top panels: Red = wind speed (kt); Green = wind gust (kt). For context, horizontal lines show mean speed boundaries on the Beaufort scale. Grey = Force 6 "Strong breeze" $(22 \mathrm{kt})$; Turquoise = Force 8 "Gale" $(34 \mathrm{kt})$; and Black = Force 10 "Storm" ( $48 \mathrm{kt})$. Note the different scales for wind speed. Bottom panels: Direction of wind speeds and gusts $\left.{ }^{\circ}\right)$. 

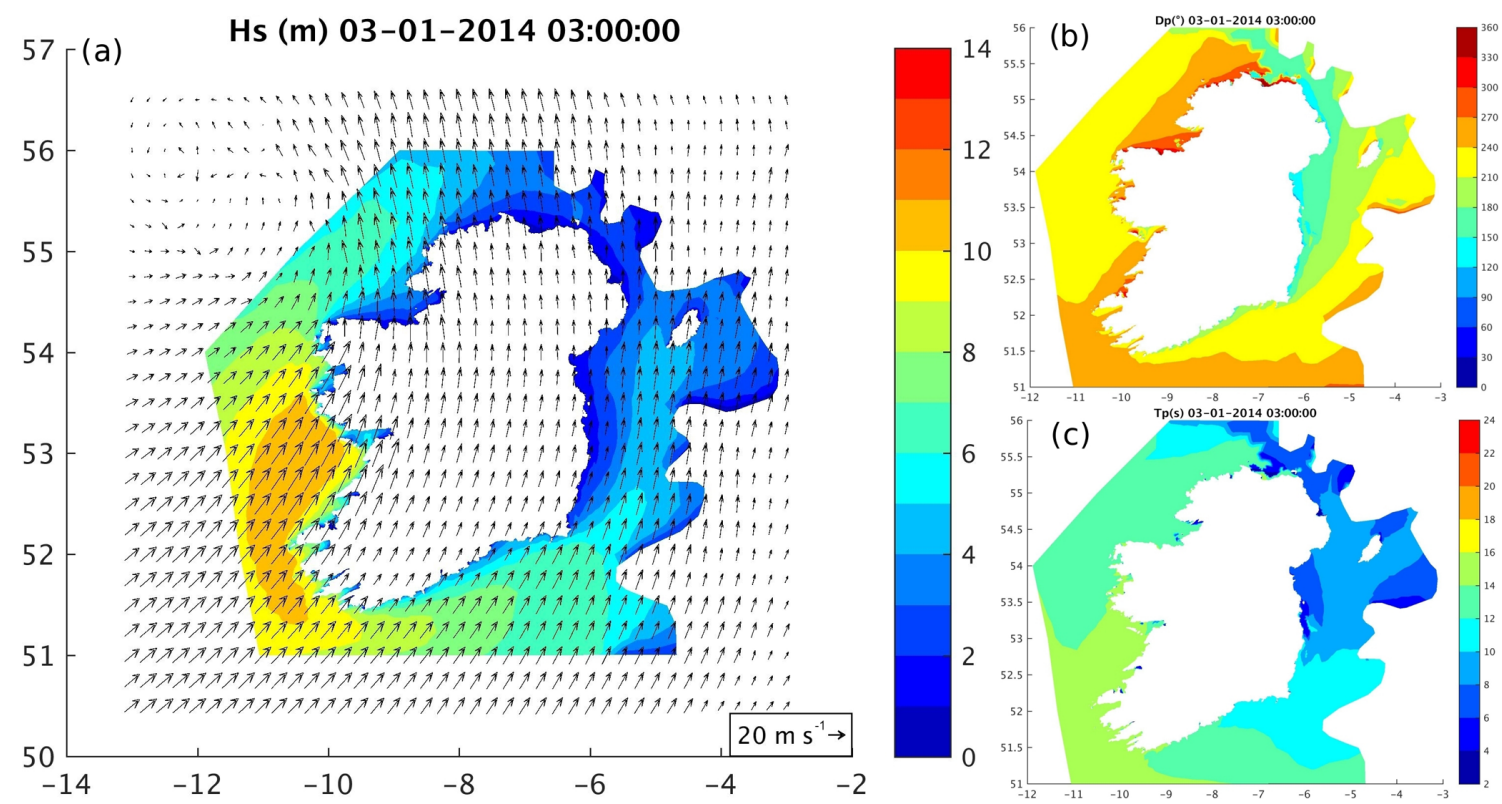

Figure 10. Maps of (a) significant wave height $(\mathrm{m})$ with vectors representing wind speed $\left(\mathrm{m} \mathrm{s}^{-1}\right)$ and direction $\left(^{\circ}\right)$, (b) peak wave direction $\left({ }^{\circ}\right)$, and (c) peak wave period (s) at 03:00 UTC on 3 January 2014.

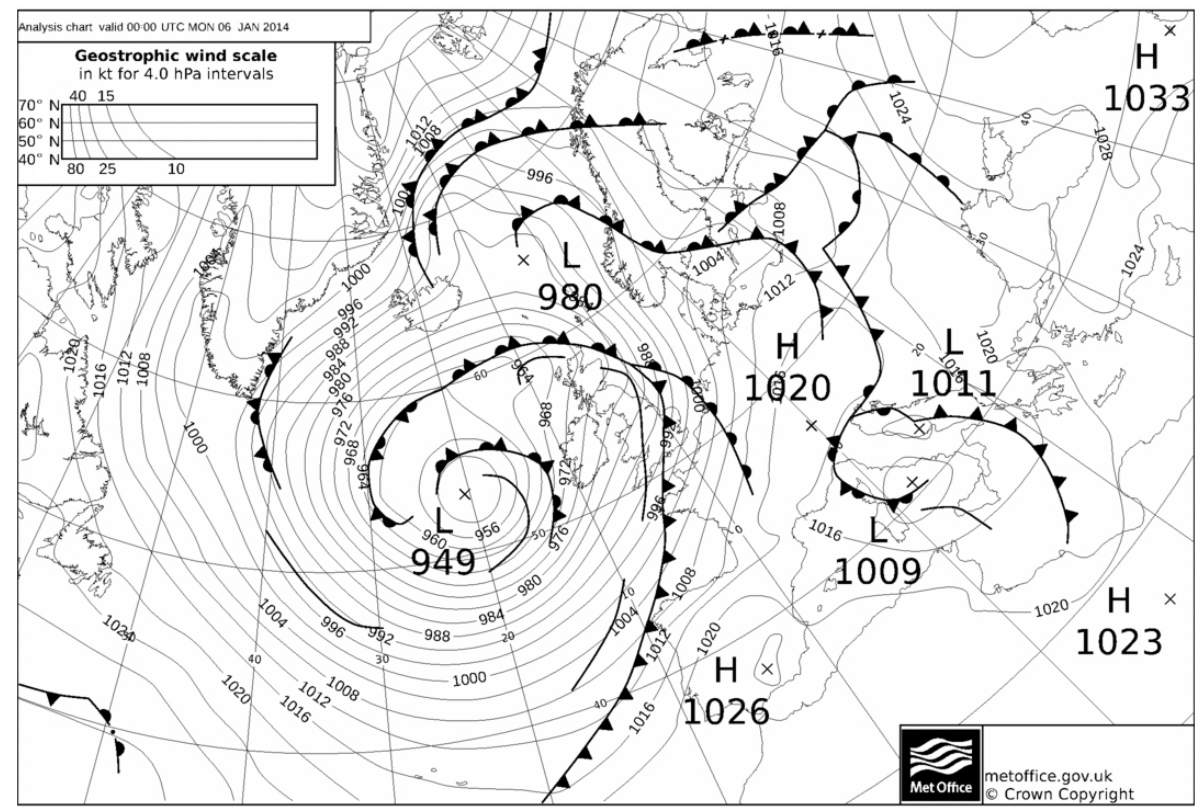

Figure 11. Synoptic chart of the storm "Hercules" on 6 January 2014 at 00:00 UTC. (C) Crown Copyright (Met Office, UK).

Scotland and western England were also affected by flooding, due to the high tides and strong winds that accompanied the storm. Many people were evacuated from their homes and at least one death due to immersion was also reported (BBC, 2014).

The wind speeds, gusts and wind direction on 3 January for Mace Head and Sherkin Island stations can be seen in Fig. 9. The wind direction ranged from approximately 200 to $270^{\circ}$ for both stations, with wind speeds from strong breeze to storm force 10 . Wind gusts reached maximum speeds of $70 \mathrm{kt}$ at Mace Head. Maximum values of $H_{\mathrm{s}}$ of $10.8 \mathrm{~m}$ were reached at 03:00 UTC on 3 January, $61 \mathrm{~km}$ southwest of the Aran Islands, Co Galway. The peak wave direction ranged from 210 to $270^{\circ}$ and the $T_{\mathrm{p}}$ was from 12 to $14 \mathrm{~s}$ (see Fig. 10). In Fig. 10 a distorted wind field can be seen in the northwest part of the model domain indicating the passing of the low 

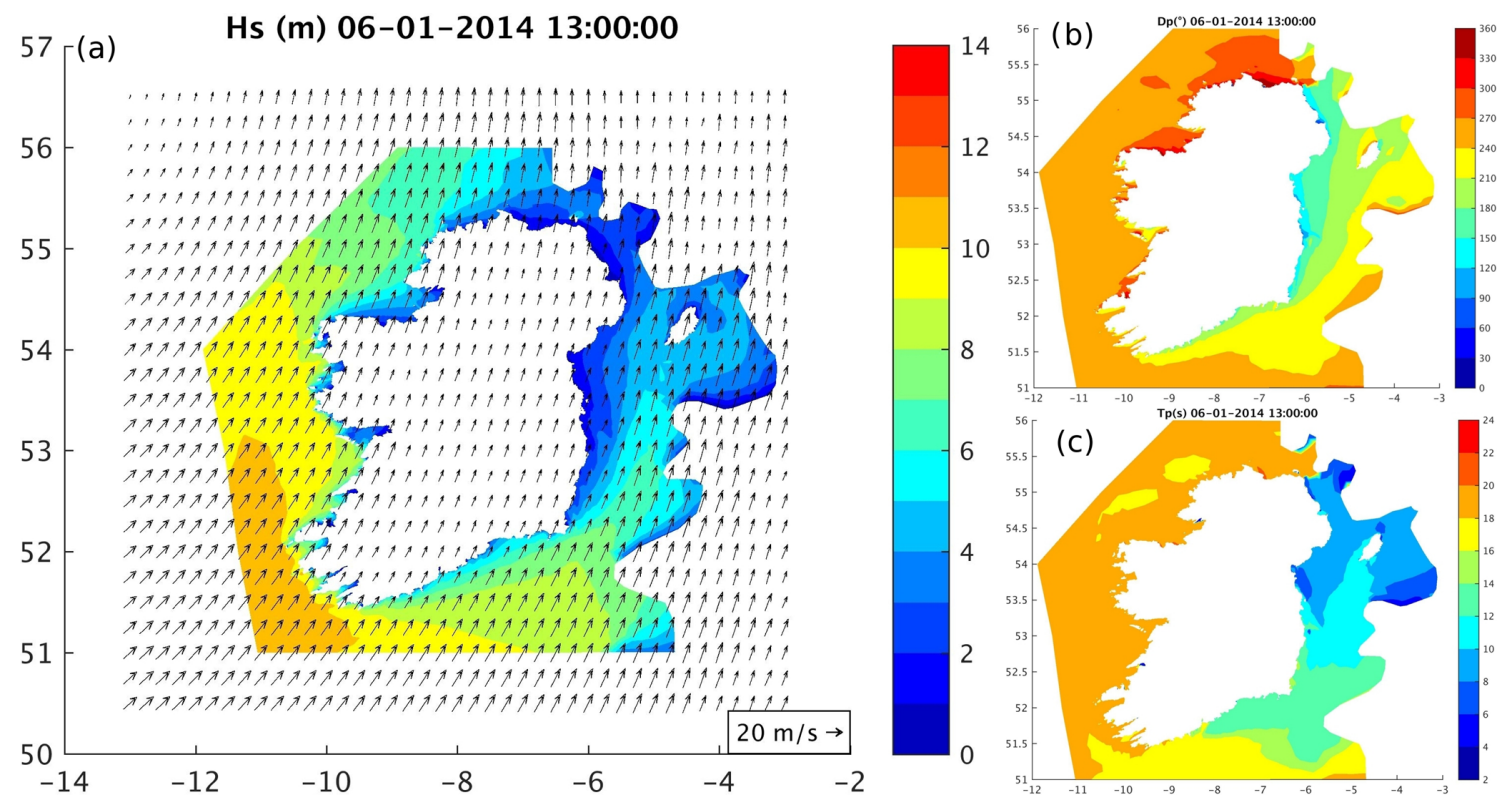

Figure 12. Maps of (a) significant wave height $(\mathrm{m})$ with vectors representing wind speed $\left(\mathrm{m} \mathrm{s}^{-1}\right)$ and direction $\left(^{\circ}\right)$, (b) peak wave direction $\left({ }^{\circ}\right)$, and (c) peak wave period (s) at 13:00 UTC on 6 January 2014 during storm "Hercules".

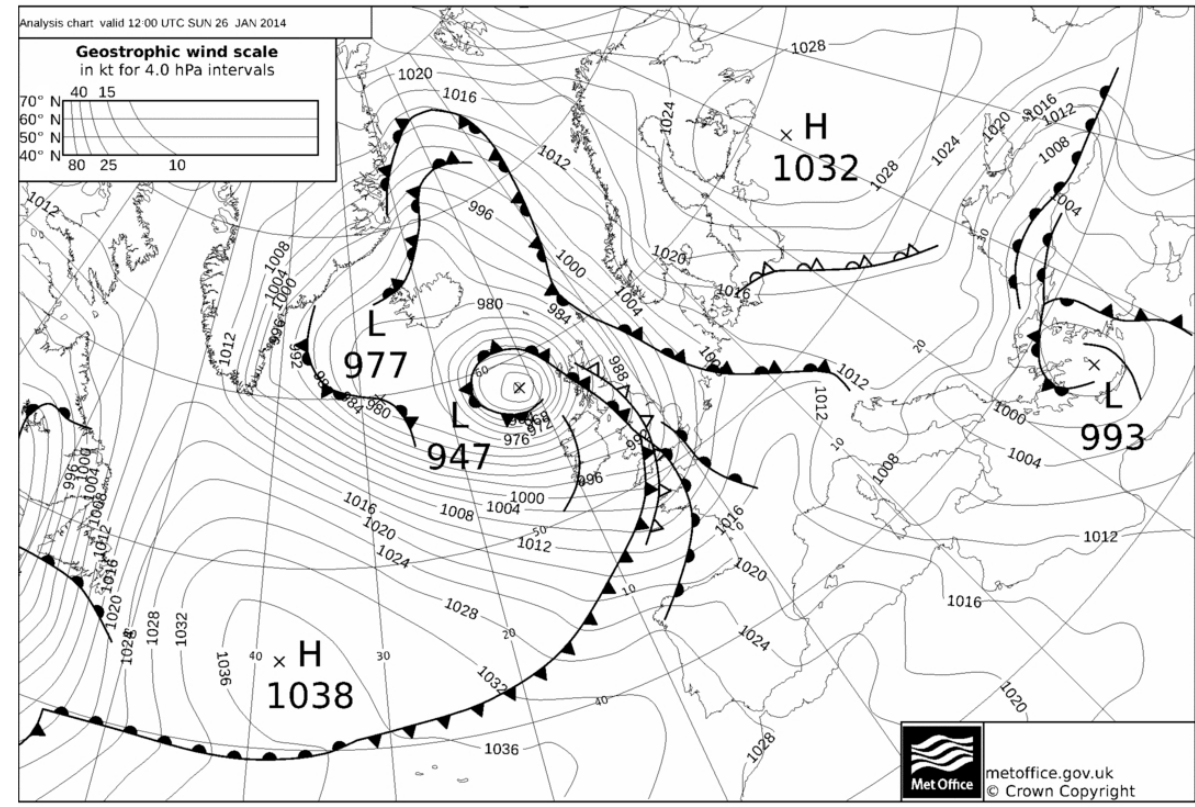

Figure 13. Synoptic chart of the storm on 26 January 2014 at 12:00 UTC. The depression tracked to the north-west of Ireland causing record breaking waves and phenomenal sea-states $\left(H_{\mathrm{S}}>14 \mathrm{~m}\right)$. @ Crown Copyright (Met Office, UK).

pressure system centre that caused the months lowest pressure value recorded by Valentia Observatory of $956 \mathrm{hPa}$.

\section{3 "Hercules" storm from 5-6 January 2014}

On 5 January Ireland was hit by a storm, named "Hercules" by the media (Ponce de León and Guedes Soares, 2015; Ponce de León et al., 2016), that brought heavy showers with intermittent dry periods or light rain and strong, south to southwest winds (Met Éireann, 2017b). The following day was affected by a band of heavy thundery rain moving across the country from west to east. Heavy thundery showers transitioned to longer spells of rain. On 6 January wind speeds were from very strong to gale with a southwestern direction. Interestingly, the heaviest lightning activity of all the days in 
(a)
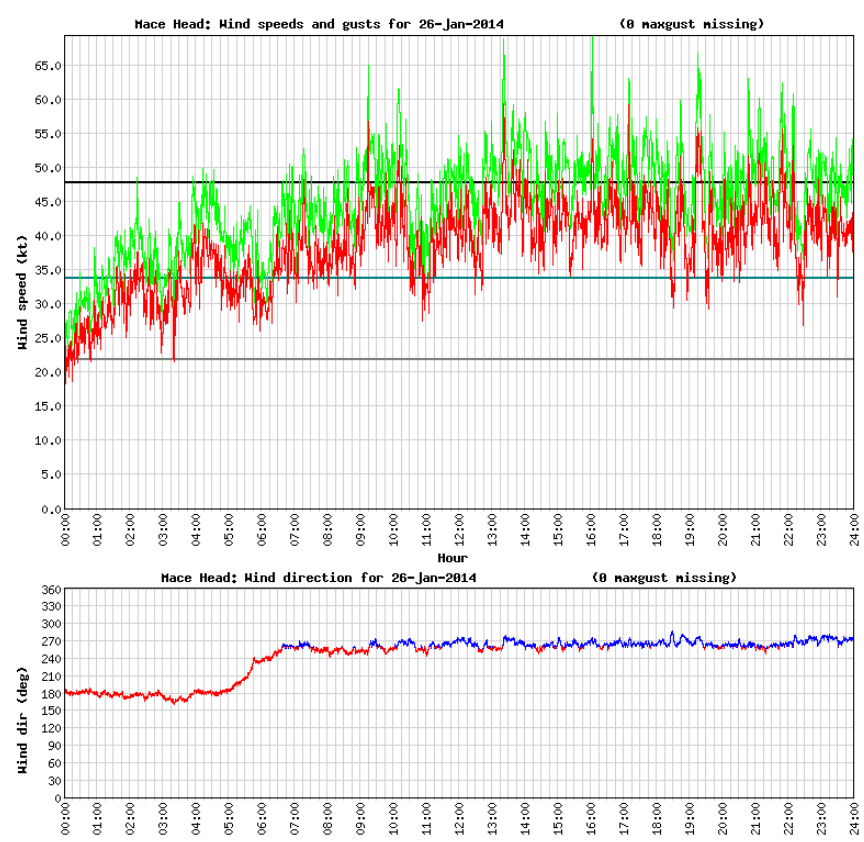

(b)
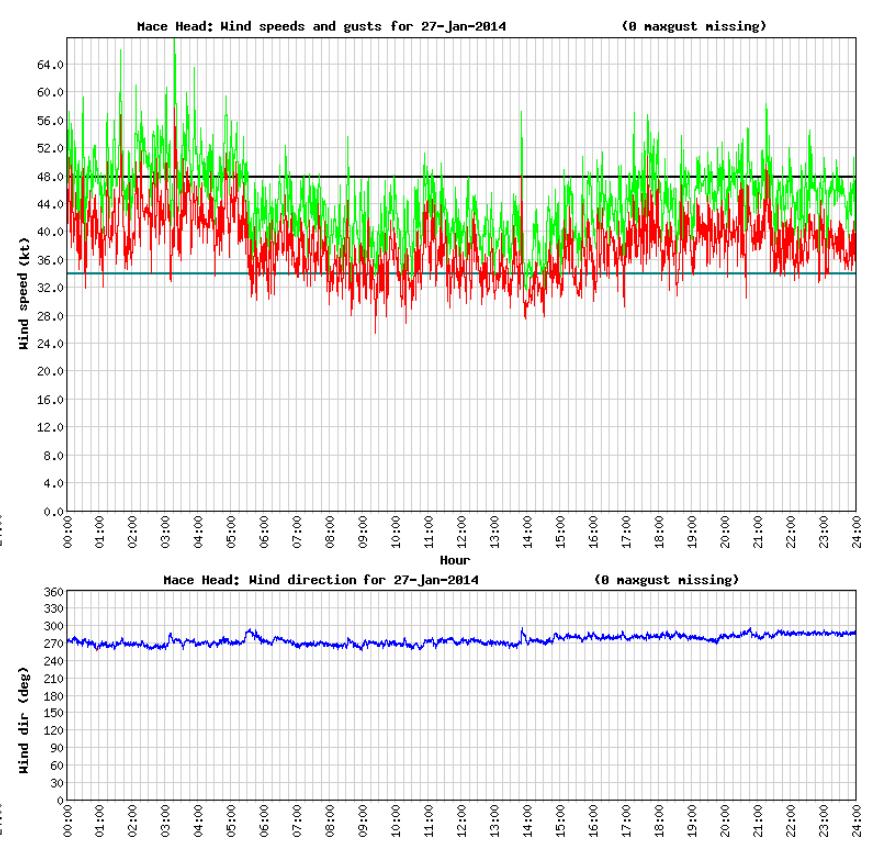

Figure 14. Observations from Met Éireann Synoptic (TUCSON) stations at Mace Head for wind speeds and gusts (top panels) and direction (bottom panels) on (a) 26 January and (b) 27 January 2014. Top panels: Red = wind speed (kt); Green = wind gust (kt). For context, horizontal lines show mean speed boundaries on the Beaufort scale. Grey = Force 6 "Strong breeze" ( $22 \mathrm{kt})$; Turquoise = Force 8 "Gale" ( $34 \mathrm{kt})$; and Black $=$ Force 10 "Storm" $(48 \mathrm{kt})$. Note the different scales for wind speed. Bottom panels: Direction of wind speeds and gusts $\left({ }^{\circ}\right)$.
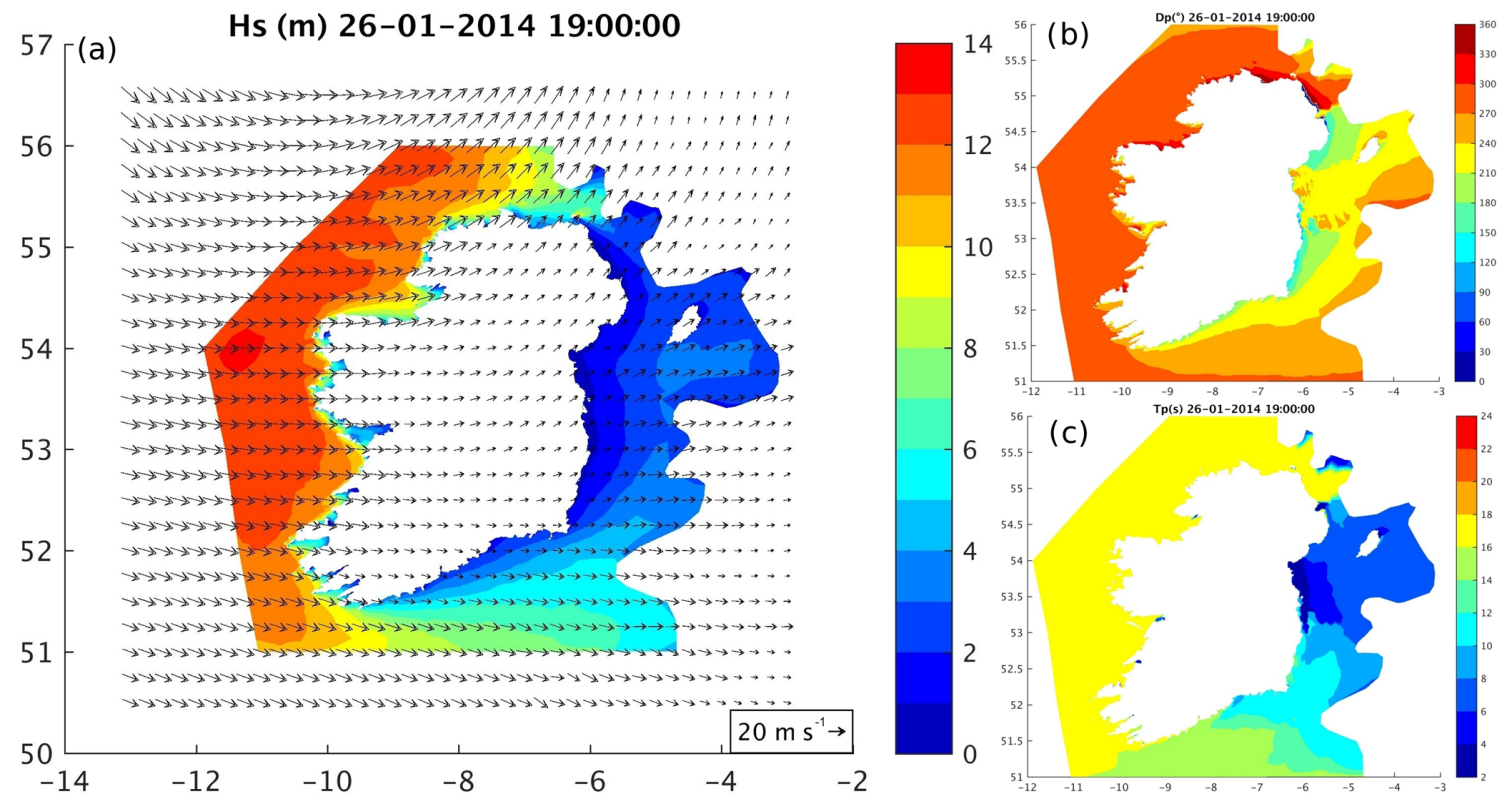

Figure 15. Maps of (a) significant wave height $(\mathrm{m})$ with vectors representing wind speed $\left(\mathrm{m} \mathrm{s}^{-1}\right)$ and direction $\left(^{\circ}\right)$, (b) peak wave direction $\left({ }^{\circ}\right)$, and (c) peak wave period (s) at 19:00 UTC on 26 January 2014. 
the month was on 6 January (Met Éireann, 2017b). The low pressure system of $949 \mathrm{hPa}$, which caused the weather situation on the 6th, can be seen in Fig. 11 approaching the west coast of Ireland from the southwest. This system brought strong to gale force wind speeds to all three synpotic stations with winds gusting up to $60 \mathrm{kt}$ at Sherkin Island and wind direction with a wide range from 120 to $240^{\circ}$ at the same station.

The maximum value of $H_{\mathrm{s}}$ of $10.9 \mathrm{~m}$ was achieved on 6 January at 13:00 UTC close to Mizen Head, Co Cork. During the day, the storm $D_{\mathrm{p}}$ ranged from 240 to $270^{\circ}$ and $T_{\mathrm{p}}$ was between 16 and $20 \mathrm{~s}$ (see Fig. 12).

\subsection{Storm on 26-27 January 2014}

On the 26th heavy rain started in the west and northwest and gradually spread over the rest of the country (Met Éireann, 2017b). By 06:00 UTC on the 26th centre of the low had deepened to $950 \mathrm{hPa}$ (see Fig. 13) and by 12:00 UTC had deepened further to $947 \mathrm{hPa}$, located to the northwest of Ireland, bringing gale force winds and phenomenal sea-states. When $H_{\mathrm{s}}$ is $14 \mathrm{~m}$ or greater, the World Meteorological Organization (WMO) defines these as phenomenal seas (WMO, 2009). Heavy showers, some even with hail, continued during the day all over the country. The situation continued on the 27th with heaviest and most frequent showers in the west and northwest of the country. On this day winds were strong to gale wind with a westerly direction (Met Éireann, 2017b).

The low pressure system on 26 January 2014 (see Fig. 13) resulted in a record $23.44 \mathrm{~m}$ maximum individual wave height at the M4 wave buoy at 15:00 UTC on the same day off the coast of Donegal, in $H_{\mathrm{s}}$ of over $14.65 \mathrm{~m}$ and mean wave period of $13.24 \mathrm{~s}$ (Tiron et al., 2014). Phenomenal sea-states were also seen all along the western seaboard as demonstrated at the Killard buoy, where $H_{\mathrm{s}}$ observations during the storm exceeded $15 \mathrm{~m}$ on more than one occasion (see Fig. 3).

Figure 14 shows the wind speeds, gusts and direction for Mace Head on 26 and 27 January. The wind speeds on the 26th ranged from strong breeze to storm force while on the 27th for Mace Head they were from gale to storm force winds (Fig. 14). The wind gust reached $70 \mathrm{kt}$ on the 26th at Mace Head. The wind direction has changed from 180 to $270^{\circ}$ in just two hours on the 26th (from 05:00 to 07:00 UTC), while the 27th it stayed relatively constant during the day between 270 to $300^{\circ}$.

The maximum $H_{\mathrm{s}}(13.1 \mathrm{~m})$ the model reached was on 26 January at 19:00 UTC $70 \mathrm{~km}$ west of Black Rock, Co Mayo, but the value of $H_{\mathrm{s}}$ stayed around $13 \mathrm{~m}$ from 13:0021:00 UTC that day. Hence comparing the measured values we can see that the model underestimated the peak value of $H_{\mathrm{s}}$ by $1.5 \mathrm{~m}$. The direction ranged from 270 to $300^{\circ}$ with $T_{\mathrm{p}}$ from 16 to $18 \mathrm{~s}$ (Fig. 15).

\section{Conclusions}

This study used the WAVEWATCH III model to reproduce the events of winter 2013/2014. We simulated December and January of this winter and analysed four storms: 5 December 2013, 3, 5-6, and 26-27 January 2014. The maximum $H_{\mathrm{s}}$ height of $13.1 \mathrm{~m}$ was reached by the model on 26 January at 19:00 UTC, keeping in mind that the model underestimated the value of $H_{\mathrm{s}}$ by $1.5 \mathrm{~m}$ when compared to the observations. The model did reproduce the extreme wave events as can be seen in the validation, but underestimated the maximum values somewhat. Phenomenal sea-states occurred off the west coast of Ireland during the winter of 2013/2014, and these extreme wave events need to be taken in account not only in the stage of WEC design, deployment, and operation but also to improve our understanding and forecasting of these extreme coastal hazards. The future work will include carrying out this simulation with higher resolution winds, ECMWF operational archive 2-D wave spectra and refining of model wind input and dissipation scheme to match more closely the peaks of these powerful storms.

Data availability. The wave data will be publically available in the future and in the meantime contact the corresponding author. The wind data used in the analysis (from Met Éireann Tucson stations) is available online: https://www.met.ie/climate/ available-data/historical-data (last access: 28 November 2017).

Competing interests. The authors declare that they have no conflict of interest.

Special issue statement. This article is part of the special issue "17th EMS Annual Meeting: European Conference for Applied Meteorology and Climatology 2017'. It is a result of the EMS Annual Meeting: European Conference for Applied Meteorology and Climatology 2017, Dublin, Ireland, 4-8 September 2017.

Acknowledgements. This work is supported by Science Foundation Ireland (SFI) through Marine Renewable Energy Ireland (MaREI), the SFI Centre for Marine Renewable Energy Research(12/RC/2302). The authors want to thank the Irish Centre for High-End Computing (ICHEC) for the provision of computational facilities. The authors thank Met Éireann for providing the M4 and Kinsale Gas Energy Platform wave data, and the ESB for the Killard Waverider buoy data. The authors thank Met Éireann for providing the M4 and Kinsale Gas Energy Platform wave data, the ESB for the Killard Waverider buoy data, wind and gust data.

Edited by: Conor Sweeney

Reviewed by: Reduan Atan and one anonymous referee 


\section{References}

Ardhuin, F., Rogers, E., Babanin, A. V., Filipot, J., Magne, R., Roland, A., van der Westhuysen, A., Queffeulou, P., Lefevre, J., Aouf, L., and Collard, F.: Semiempirical Dissipation Source Functions for Ocean Waves. Part I: Definition, Calibration, and Validation, J. Phys. Oceanogr., 40, 1917-1941, 2010, https://doi.org/10.1175/2010JPO4324.1, 2010.

BBC: BBC news - Flooding continues to threaten UK, available at: http://www.bbc.com/news/uk-25584221, last access: 21 November 2017.

Dangendorf, S., Arns, A., Pinto, J. G., Ludwig, P., and Jensen, J.: A century of sea level data and the UK's 2013/14 storm surges: An assessment of extremes and clustering using the newlyn tide gauge record, Environ. Res. Lett. 11, 054001, https://doi.org/10.1088/1748-9326/11/5/054001, 2016.

Dee, D. P., Uppala, S. M., Simmons, A. J., Berrisford, P., Poli, P., Kobayashi, S., Andrae, U., Balmaseda, M. A., Balsamo, G., Bauer, P., Bechtold, P., Beljaars, A. C. M., van de Berg, L., Bidlot, J., Bormann, N., Delsol, C., Dragani, R., Fuentes, M., Geer, A. J., Haimberger, L., Healy, S. B., Hersbach, H., Hólm, E. V., Isaksen, L., Kållberg, P., Köhler, M., Matricardi, M., McNally, A. P., Monge-Sanz, B. M., Morcrette, J.-J., Park, B.-K., Peubey, C., de Rosnay, P., Tavolato, C., Thépaut, J.-N., and Vitart, F.: The ERA-Interim reanalysis: configuration and performance of the data assimilation system, Q. J. Roy. Meteor. Soc., 137, 553-597, https://doi.org/10.1002/qj.828, 2011.

EMODnet: MODNET - the European marine observation and data network, available at: http://portal.emodnet-hydrography.eu (last access: 28 November 2017), 2013.

Gallagher, S., Tiron, R., and Dias, F.: A long-term nearshore wave hindcast for Ireland: Atlantic and Irish Sea coasts (1979-2012), Ocean Dynam., 64, 1163-1180, 2014.

Gallagher, S., Gleeson, E., Tiron, R., McGrath, R., and Dias, F.: The Nearshore Wind and Wave Energy Potential of Ireland: A High Resolution Assessment of Availability and Accessibility, Renew. Energ., 88, 494-516, https://doi.org/10.1016/j.renene.2015.11.010, 2016a.

Gallagher, S., Gleeson, E., Tiron, R., McGrath, R., and Dias, F.: Wave climate projections for Ireland for the end of the 21 st century including analysis of Earth winds over the North Atlantic Ocean, Int. J. Climatol., 36, 4592-4607, 2016 b.

Gleeson, E., Gallagher, S., Clancy, C., and Dias, F.: NAO and extreme ocean states in the Northeast Atlantic Ocean, Adv. Sci. Res., 14, 23-33, 2017.

Irish Times: High tides and storm cause flooding across country: available at: https://www.irishtimes.com/news/environment/ high-tides-and-storm-cause-flooding-across-country-1. 1642813, last access: 9 November 2017.

MATLAB: MATLAB and Statistics Toolbox Release R2015b, The MathWorks, Inc., Natick, Massachusetts, United States, 2015.

Matthews, T. K. R., Murphy, C., Wilby, R. L., and Harrigan, S.: Stormiest winter on record for Ireland and UK, Nat. Clim. Change, 4, 738-740, https://doi.org/10.1038/nclimate2336, 2014.

Masselink, G., Castelle, B., Scott, T., Dodet, G., Suanez, S., Jackson, D., and Floc'h, F.: Extreme wave activity during 2013/2014 winter and morphological impacts along the At- lantic coast of Europe, Geophys. Res. Lett., 43, 2135-2143, https://doi.org/10.1002/2015GL067492, 2016.

Met Éireann: Winter 2013/2014: available at: http://www.met.ie/ climate-ireland/weather-events/WinterStorms13_14.pdf, last access: 23 November 2017 a.

Met Éireann: January 2014 Monthly Weather Bulletin No. 332, available at: https://www.met.ie/climate/ irish-climate-monthly-summary.asp, last access: 3 November $2017 b$.

Met Éireann: December 2013 Monthly Weather Bulletin No. 332, available at: http://www.met.ie/climate/MonthlyWeather/ clim-2013-Dec.pdf, last access: 3 November 2017c.

Met Office: Winter 2013/14, available at: https://www.metoffice. gov.uk/climate/uk/summaries/2014/winter, last access: 14 November 2017a.

Met Office: Winter storms, January to February 2014, available at: https://www.metoffice.gov.uk/climate/uk/interesting/ 2014-janwind, last access: 8 November 2017 b.

Met Office: Winter storms, December 2013 to January 2014, available at: https://www.metoffice.gov.uk/climate/uk/interesting/ 2013-decwind, last access: 8 November 2017c.

Ponce de León, S. and Guedes Soares, C.: Hindcast of the Hercules winter storm in the North Atlantic, Nat. Hazards, 78, 1883-1897, 2015.

Ponce de León, S., Bettencourt, J. H., and Dias, F.: Comparison of numerical hindcasted severe waves with Doppler radar measurements in the North Sea, Ocean Dynam., 67, 103-115, https://doi.org/10.1007/s10236-016-1014-3, 2016.

Risk Management Solutions (RMS): 2013-2014 Winter storms in europe, An Insurance and Catastrophe Modeling Perspective, available at: http://forms2.rms.com/rs/729-DJX-565/ images/ws_2013_2014_europe_winter_storms.pdf, last access: 15 November 2017.

Roland, A.: Development of WWM II: Spectral wave modelling on unstructured meshes, Institut für Wasserbau und Wasserwirtschaft, Technische Universität Darmstadt, 2008.

Tiron, R., Gallagher, S., and Dias, F.: UCD School of Mathematical Sciences is tracking record extreme waves off the west coast of Ireland, available at: http://www.ucd.ie/mathstat/newsandevents/ news/newsarchive/maintext, 196126,en.html (last access: 15 November 2017), 2014.

Tolman, H.: The WAVEWATCH III Development Group (2014), User Manual and System Documentation of WAVEWATCH III version 4.18, Tech. Note 316, NOAA/NWS/NCEP/MMAB, 2014, available at: http://polar.ncep.noaa.gov/waves/wavewatch/ manual.v4.18.pdf (last access: 23 November 2017), 2014.

Wadey, M. P., Haigh, I. D., and Brown, J. M.: A century of sea level data and the UK's 2013/14 storm surges: an assessment of extremes and clustering using the Newlyn tide gauge record, Ocean Sci., 10, 1031-1045, https://doi.org/10.5194/os-10-10312014, 2014.

Wild, S., Befort, D. J., and Leckebusch, G. C.: Was the Extreme Storm Season in Winter 2013/14 Over the North Atlantic and the United Kingdom Triggered by Changes in the West Pacific Warm Pool?, B. Am. Meteorol. Soc., 96, S29-S34, https://doi.org/10.1175/BAMS-D-15-00118.1, 2016.

World Meteorological Organization: Guide to Meteorological Instruments and Methods of Observation - WMO-No.8: part II, 
chap. 4 (Marine Observations), World Meteorological Society, 7th Edn., 2009.

Wolf, D. and Wolf, J.: Impact of climate change on storms and waves, MCCIP Science Review 2013, 20-26, https://doi.org/10.14465/2013.arc03.020-026, 2013. 